\title{
Penyelesaian Sengketa Konsumen dan Pelaku Usaha dalam Transaksi E-Commerce Melalui Sistem Cash On Delivery
}

\author{
Silviasari \\ Program Studi Hukum, Fakultas Hukum, Universitas Muhammadiyah Yogyakarta, Indonesia \\ E-mail: silviamarsellona@gmail.com
}

\section{Info Artikel}

Diajukan: 26-06-2020

Direview: 18-08-2020

Direvisi: 24-08-2020

Diterima: 25-08-2020

DOI: $10.18196 / \mathrm{mls} . v 1 i 3.9192$

\begin{abstract}
Abstrak
Cash On Delivery (COD) jika diartikan adalah berarti membayar barang pada saat barang dikirimkan. Transaksi dengan sistem COD dilakukan pada saat konsumen dan penjual bertemu secara langsung di suatu tempat yang telah disepakati sebelumnya, sehingga pembeli mendapatkan keuntungan karena barang yang dipesan bisa diperiksa terlebih dahulu sebelum melakukan pembayaran. Kenyataan terjadi beberapa kasus yang menimbulkan kerugian yang
\end{abstract} dirasakan oleh pihak penjual dalam sebuah transaksi jual-beli dengan sistem COD, antara lain : barang yang dikirim sesuai dengan pesanan dan pembeli tidak tanggung jawab dalam pembayaran melalui COD karena pembeli tidak dapat dihubungi atau tidak jujur dalam memberikan informasi tentang alamat pembeli, karena adanya wanprestasi dan penjual menanggung biaya pengiriman tersebut. Penelitian ini bertujuan untuk mengetahui bagaimana perlindungan hukum terhadap konsumen dan pelaku usaha dalam jual beli secara cash on delivery dan mengetahui bagaimana penyelesaian sengketa dalam transaksi jual beli secara cash on delivery dalam Undang-Undang Nomor 8 Tahun 1999 tentang Perlindungan Konsumen, Undang-Undang Nomor 11 Tahun 2008 tentang Informasi dan Transaksi Elektronik (ITE), Undang-Undang Nomor 7 Tahun 2014. Metode yang digunakan dalam penelitian ini adalah penelitian hukum normative. Hasil dari penelitian ini adalah perlindungan hukum konsumen dan pelaku usaha serta bagaimana penyelesaian sengketa dalam transaksi jual beli secara cash on delivery berdasarkan Undang-Undang Nomor 8 Tahun 1999 tentang Perlindungan Konsumen, Undang-Undang Nomor 11 Tahun 2008 tentang Informasi dan Transaksi Elektronik (ITE), Undang-Undang Nomor 7 Tahun 2014. Kata kunci: cash on delivery; penyelesaian sengketa; perlindungan hukum

\section{Pendahuluan}

Perkembangan teknologi membuat penyelenggaraan transaksi perdagangan semakin modern. Dengan menggunakan internet, setiap orang dapat bertransaksi secara bebas dan melewati batas-batas geografis. Namun demikian, pemanfaatan teknologi dalam transaksi E-commerce tetap memiliki resiko sengketa. Oleh karena itu, perlu ada mekanisme penyelesaian sengketa yang dapat mengakomodir kepentingan para pihak dalam transaksi E-commerce. Kedudukan konsumen dalam transaksi E-commerce juga menjadi sangat penting karena konsumen memiliki kedudukan yang lemah dalam bertransaksi dengan pelaku usaha. Dengan demikian, penyelenggaraan transaksi $E$ - 
commerce dan penyelesaian sengketanya juga harus mempertimbangkan upaya perlindungan terhadap konsumen. ${ }^{1}$

E-commerce adalah segala aktivitas jual beli yang dilakukan melalui media elektronik. Istilah E-commerce digunakan untuk mendeskripsikan semua transaksi yang memakai media elektronik. Marketplace sendiri adalah salah satu model E-commerce, di mana ia berfungsi sebagai perantara antara penjual dan pembeli. Penjual yang berdagang di marketplace hanya perlu meladeni pembelian. Semua aktivitas lain seperti pengelolaan website sudah diurus oleh platform tersebut. Situs-situs seperti Shopee dan Lazada adalah dua contoh marketplace. ${ }^{2}$

Cash On Delivery (COD) adalah metode pembayaran dimana anda bisa membayar pesanan secara tunai pada saat pesanan tiba di tujuan. Pembayaran dilakukan kepada kurir yang mengantarkan barang. Pembayaran kepada kurir hanya bisa dilakukan secara tunai. Apabila anda tidak ingin membayarkan secara tunai, anda dapat memilih metode pembayaran lain yang kami sediakan. Demi kelancaran transaksi, mohon disiapkan uang pas pada saat pengantaran barang. Cara untuk mengatasi permasalahan tersebut karena penjual dan pembeli dapat bertemu secara langsung.

Dalam jual beli E-commerce dengan sistem COD penjual akan memuat produk atau barang yang akan dijualnya melalui foto produknya dengan mencantumkan spesifikasi barang, harga dan nomor penjual. ${ }^{3}$ Keuntungan bagi pembeli dalam transaksi E-commerce dengan sistem COD, pembeli dapat memeriksa barang terlebih dahulu sebelum melakukan pembayaran kepada penjual. Kerugian bagi penjual dalam transaksi E-commerce terjadi wanprestasi dalam jual-beli online, di mana barang yang sudah dikirim sesuai dengan pesanan kemudian pembeli tidak tanggung jawab dalam pembayaran melalui Cash On Delivery (COD) karena pembeli tidak dapat dihubungi atau tidak jujur dalam memberikan informasi.

Dalam hal transaksi antara pelaku usaha dengan konsumen pada penyelenggaraan E-commerce, maka penyelenggaraan transaksi tersebut terikat dengan ketentuan perlindungan konsumen. Hal ini didasari atas kondisi dimana satu pihak selalu memiliki kedudukan yang lebih diuntungkan. Konsumen dalam hal ini menjadi objek aktivitas bisnis untuk meraup keuntungan sebesar-besarnya oleh pelaku usaha melalui promosi, cara penjualan, serta penerapan perjanjian standar yang merugikan konsumen. ${ }^{4}$ Lebih khusus lagi, dalam transaksi perdagangan secara online, konsumen sering kali dihadapkan dengan perilaku pelaku usaha yang tidak bertanggung jawab. Hal ini semakin mudah dilakukan oleh pelaku usaha karena para pihak tidak saling bertemu secara langsung pada saat terjadi kesepakatan Oleh karena itu, seperti halnya dalam perdagangan konvensional, transaksi perdagangan secara online atau E-commerce

\footnotetext{
${ }^{1}$ http://www.lib.ui.ac.id/naskahringkas/2015-08/S-Muhammad\%20Rizaldi diakses pada tanggal 14 Desember 2019 pukul 23.00 WIB

${ }^{2}$ https://www.niagahoster.co.id/blog/apa-itu-ecommerce/ diakses pada tanggal 15 Desember 2019 pukul 00.45 WIB

${ }^{3}$ https://infopeluangusaha.org/arti-dan-penjelasan-cod-dalam-jual-belidiaksespada 10 November 2019pukul 4.30 WIB

${ }^{4}$ Lihat penjelasan umum Undang-Undang No. 8 Tahun 1999 Tentang Perlindungan Konsumen (UUPK)
} 
antara pelaku usaha dan konsumen harus juga diberikan perlindungan hukum terhadap konsumen. Perlu ada upaya perlindungan konsumen dalam penyelenggaraan transaksi E-commerce baik sebelum terjadi sengketa maupun setelah terjadi sengketa.

Mekanisme transaksi jual beli pada Kitab Undang-Undang Hukum Perdata (selanjutnya disebutkan KUHPerdata), dapat dilakukan melalui perjanjian terlebih dahulu. Menurut ketentuan Pasal 1313 KUHPerdata bahwa perjanjian adalah suatu perbuatan dengan mana satu orang atau lebih mengikatkan dirinya kepada satu orang atau lebih lainnya sedangkan jualbeli merupakan suatu perjanjian antara pihak penjual yang memberikansuatubenda yang dijualnyadan pihak yang membayar nilai benda yang diperjanjikan sesuai harga yang disepakati dan sifatnya mengikat. Masalah yang akan diuraikan adalah Bagaimana penyelesaian sengketa dalam transaksi $e$-commerce dengan sistem Cash On Delivery (COD)?

\section{Metode}

Metode penulisan dalam penelitian ini menggunakan metode yuridis normatif. Data yang digunakan adalah data sekunder yang diperoleh dari dokumen resmi, bukubuku, hasil penelitian, hasil laporan, buku harian, surat kabar, makalah dan literatur hukum di berbagai sumber tertulis lainnya yang relevan. Pengolahan data dilakukan dengan cara mesistematika terhadap bahan-bahan hukum tertulis. Kegiatan yang dilakukan dalam analisis data penelitian hukum normatif dengan cara data yang diperoleh di analisis secara preskriptif terhadap data yang tidak bisa dihitung dengan pendekatan perundang-undangan (statute approach). Bahan hukum yang diperoleh selanjutnya dilakukan pembahasan, pemeriksaan dan pengelompokan ke dalam bagianbagian tertentu untuk diolah menjadi data informasi.

\section{Hasil dan Pembahasan}

Tinjauan Umum Tentang Jual Beli Online secara E-Commerce menurut UndangUndang Perdagangan Undang-Undang Nomor 7 Tahun 2014 Pasal 1 ayat 24 bahwa perdagangan melalui sistem elektronik (E-Commerce) adalah perdagangan yang transaksinya dilakukan melalui serangkaian perangkat dan prosedur elektronik. ${ }^{5}$

Undang-Undang Nomor 7 tahun 2014 Pasal 65 menjelaskan bahwa perdagangan melalui sistem elektronik ${ }^{6}$ :

1) Setiap Setiap Pelaku Usaha yang memperdagangkan Barang dan/atau Jasa dengan menggunakan sistem elektronik wajib menyediakan data dan/atau informasi secara lengkap dan benar.

2) Setiap Pelaku Usaha dilarang memperdagangkan Barang dan/atau Jasa dengan menggunakan sistem elektronik yang tidak sesuai dengan data dan/atau informasi sebagaimana dimaksud pada ayat (1).

\footnotetext{
${ }^{5}$ Undang-Undang Nomor 7 Tahun 2014 tentang Perdagangan

${ }^{6}$ Ibid.
} 
3) Penggunaan sistem elektronik sebagaimana dimaksud pada ayat (1) wajib memenuhi ketentuan yang diatur dalam Undang-Undang Informasi dan Transaksi Elektronik.

4) Data dan/atau informasi sebagaimana dimaksud pada ayat (1) paling sedikit memuat:

a) Identitas dan legalitas Pelaku Usaha sebagai produsen atau Pelaku Usaha Distribusi

b) Persyaratan teknis Barang yang ditawarkan

c) Persyaratan teknis atau kualifikasi Jasa yang ditawarkan

d) Harga dan cara pembayaran Barang dan/atau Jasa

e) Cara penyerahan barang.

5) Dalam hal terjadi sengketa terkait dengan transaksi dagang melalui sistem elektronik, orang atau badan usaha yang mengalami sengketa dapat menyelesaikan sengketa tersebut melalui pengadilan atau melalui mekanisme penyelesaian sengketa lainnya.

6) Setiap Pelaku Usaha yang memperdagangkan Barang dan/atau Jasa dengan menggunakan sistem elektronik yang tidak menyediakan data dan/atau informasi secara lengkap dan benar sebagaimana dimaksud pada ayat (1) dikenai sanksi administratif berupa pencabutan izin.

Transakasi Online Menurut Undang-Undang Nomor 11 Tahun 2008 tentang Informasi dan Transaksi Elektronik. Pengertian transaksi elektronik berdasarkan Pasal 1 ayat (2) UU No. 11 Tahun 2008 menjelaskan bahwa transaksi elektronik adalah perbuatan hukum yang dilakukan dengan menggunakan komputer, jaringan komputer, dan/atau media elektronik lainnya ${ }^{7}$

Asas konsensualis memerupakan asas yang ada di dalam transaksi E-Commerce. Asas konsensualisme memiliki arti sebagai bentuk kesepakatan antara penjual dan pembeli. Kesepakatan merupakan sebuah penawaran dan penerimaan yang dilakukan oleh penjual dan pembeli. Proses penawaran dan penerimaan online ini tidaklah beda dengan proses penawaran dan penerimaan pada umumnya. Perbedaannya hanyalah pada media yang dipergunakan, pada transaksi e-commerce media yang digunakan adalah internet. Pasal 19 UU No.11 Tahun 2008 menjelaskan bahwa para pihak yang melakukan transaksi elektronik harus menggunakan sistem elektronik yang disepakati.

Sebelum melakukan transaksi elektronik, kesepakatan harus sudah terjadi antara penjual dan pembeli untuk menyepakati sistem elektronik yang akan digunakan untuk melakukan transaksi.Transaksi elektronik terjadi pada saat penawaran transaksi yang dikirim pengirim telah diterima dan disetujui oleh penerima sebagaimana yang ditentukan dalam Pasal 20 ayat (1) UU No. 11 Tahun 2008. Transaksi Elektronik terjadi pada saat kesepakatan antara para pihak yang dapat berupa, antara lain pengecekan data, identitas, nomor identifikasi pribadi (personal identification number/PIN) atau sandi lewat (password)

Pasal 20 ayat (2) UU No. 11 Tahun 2008 menjelaskan bahwa persetujuan atas penawaran transaksi elektronik harus dilakukan dengan pernyataan penerimaan secara elektronik $^{8}$

\footnotetext{
${ }^{7}$ Undang-Undang Nomor 11 Tahun 2008 tentang Informasi dan Transaksi Elektronik ${ }^{8}$ Ibid
} 
Undang-Undang Nomor 11 tahun 2008 Bab VIII Penyelesaian Sengketa ${ }^{9}$ :

1) Pasal 38 menyebutkan bahwa :

a) Setiap Orang dapat mengajukan gugatan terhadap pihak yang menyelenggarakan Sistem Elektronik dan/atau menggunakan Teknologi Informasi yang menimbulkan kerugian.

b) Masyarakat dapat mengajukan gugatan secara perwakilan terhadap pihak yang menyelenggarakan Sistem Elektronik dan/atau menggunakan Teknologi Informasi yang berakibat merugikan masyarakat, sesuai dengan ketentuan Peraturan Perundang-undangan

2) Pasal 39 menyebutkanbahwa :

a) Gugatan perdata dilakukan sesuai dengan ketentuan Peraturan Perundangundangan.

Selain penyelesaian gugatan perdata sebagaimana dimaksud pada ayat (1), para pihak dapat menyelesaikan sengketa melalui arbitrase, atau lembaga penyelesaian sengketa alternatif lainnya. Setiap konsumen yang dirugikan dapat menggugat pelaku usaha melalui lembaga yang bertugas menyelesaikan sengketa antara konsumen dan pelaku usaha atau melalui peradilan yang berada di lingkungan peradilan umum. Penyelesaian sengketa konsumen dapat ditempuh melalui pengadilan atau di luar pengadilan berdasarkan pilihan sukarela para pihak yang bersengketa (Pasal 45 ayat (1) dan ayat (2)). Budaya hukum masyarakat termasuk faktor yang mempengaruhi arti penting penyelesaian sengketa di luar Pengadilan. ${ }^{10}$

Dalam UU No.8 Tahun 1999 Pasal 46 tentang gugatan konsumen disebutkan bahwa gugatan atas pelanggaran pelaku usaha dapat dilakukan oleh seorang konsumen yang dirugikan atau ahli waris yang bersangkutan, sekelompok konsumen yang mempunyai kepentingan yang sama (class action), lembaga perlindungan konsumen swadaya masyarakat yang memenuhi syarat, yaitu berbentuk badan hokum atau yayasan, yang dalam anggaran dasarnya menyebutkan dengan tegas bahwa tujuan didirikannya organisasi tersebut adalah untuk kepentingan perlindungan konsumen dan telah melaksanakan kegiatan sesuai dengan anggaran dasarnya, pemerintah dan/atau instansi terkait apabila barang dan/atau jasa yang dikonsumsi atau dimanfaatkan mengakibatkan kerugian materi yang besar dan/atau korban yang tidak sedikit. ${ }^{11}$

Penyelesaian sengketa konsumen sebagaimana dimaksud dalam pasal 45 ayat (2) UUPK, tidak menutup kemungkinan dilakukannya penyelesaian secara damai oleh para pihak yang bersengketa yaitu pelaku usaha dan konsumen, tanpa melalui pengadilan atau Badan Penyelesaian Sengketa Konsumen, dan sepanjang tidak bertentangan dengan UUPK. Bahkan, dalam penjelasan pasal tersebut dikemukakan bahwa pada setiap tahap

\footnotetext{
${ }^{9}$ Ibid

${ }^{10}$ Kurniawan, Permasalahan dan Kendala Penyelesaian Sengketa Konsumen melalui Badan Penyelesaian Sengketa Konsumen (BPSK), Jurnal Dinamika Hukum, Vol 12 No. 1, Tahun 2012

${ }^{11}$ Mukti Fajar, Penyelesaian Sengketa Konsumen, Materi Perkuliahan Fakultas Hukum Universitas Muhammadiyah Yogyakarta
} 
diusahakan untuk menggunakan penyelesaian damai oleh kedua belah piak yang bersengketa. Dari penjelasan pasal 45 ayat (2) UUPK dapat diketahui bahwa UUPK menghendaki agar penyelesaian damai merupakan upaya hukum yang justru terlebih dahulu diusahakan oleh para pihak yang bersengketa, sebelum para pihak memilih untuk menyelesaikan sengketa mereka melalui BPSK atau badan peradilan.

Dalam melalukan upaya penyelesaian sengketa konsumen di luar pengadilan, Pemerintah membentuk suatu badan baru, yaitu Badan Penyelesaian Sengketa Konsumen (BPSK), untuk penyelesaian sengketa konsumen di luar pengadilan. Dengan adanya BPSK maka penyelesaian sengketa konsumen dapat dilakukan secara cepat, mudah, dan murah. ${ }^{12}$ Cepat karena UUPK menentukan dalam tenggang waktu 21 hari kerja BPSK wajib memberikan putusannya. ${ }^{13}$ Mudah karena prosedur administratif dan proses pengambilan putusan yang sangat sederhana. Murah terletak pada biaya perkara yang terjangkau. Hal ini tentunya sangat berguna dalam penyelesaian sengketa transaksi E-commerce antara pelaku usaha dan konsumen. Oleh karena itu, dalam hal penyelenggaraan transaksi E-commerce antara pelaku usaha dan konsumen, apabila terjadi sengketa akan lebih tepat diselesaikan melalui penyelesaian di luar pengadilan yaitu melalui BPSK.

Dalam UU No. 8 tahun 1999 tentang Perlindungan Konsumen upaya penyelesaian sengketa konsumen dapat melalui lembaga yang bertugas menyelesaikan sengketa (dalam hal ini Badan Penyelesaian Sengketa Konsumen) Tugas dan wewenang Badan Penyelesaian Sengketa Konsumen sebagaiamana diatur dalam Undang-undang Nomor 8 tahun 1999 tentang Perlindungan Konsumen jo. Surat Keputusan Menteri Perindustrian dan Perdagangan Nomor 350/MPP.Kep/12/2001 tentang Pelaksanaan tugas dan wewenang Badan Penyelesaian Sengketa Konsumen Berdasarkan rumusan diatas pada pasal 52, penyelesaian sengketa konsumen dilakukan dengan 3 (tiga) cara yaitu :

1) Mediasi

Mediasi Adalah cara penyelesaian sengketa melalui proses perundingan untuk memperoleh kesepakatan para pihak dengan dibantu oleh mediator. Mediator tidak berwenang untuk memutus sengketa, tetapi hanya membantu para pihak untuk menyelesaikan persoalan-persoalan yang dikuasakan kepadanya.

2) Arbitrase

Arbitrase Berasal dari kata arbitrate (latin), arbitrage (belanda), abitration (Inggris), yang berarti kekuasaan untuk menyelesaikan sesuatu menurut kebijaksanaan atau damai oleh arbiter. Arbitrase adalah penyelesaian sengketa yang dilakukan para pihak secara suka rela setuju untuk terikat pada putusan pihak ketiga yang netral di luar proses peradilan yang normal. Syarat-syarat yang harus dipatuhi oleh para pihak antara lain abitrase tidak melakukan tatap muka dilakukan melalui telephone dan media online,

\footnotetext{
${ }^{12}$ Susanti Adi Nugroho, Proses Penyelesaian Sengketa Konsumen Ditinjau Dari Hukum Acara Serta Kendala Implementasiya, (Jakarta: Kencana Prenada Media Group, 2008), hal. 99

${ }^{13}$ Indonesia, Undang-Undang Perlindungan Konsumen, UU No. 8 Tahun 1999, LN No. 42 Tahun 1999, TLN No. 3821, ps. 55.
} 
kecuali ada kesepakatan dari kedua pihak, hasil penilaian abitrase dimasukan dalam setiap pengadilan.

3) Konsiliasi

Konsiliasi Adalah usaha untuk mempertemukan keinginan pihak yang berselisih untuk mencapai suatu persetujuan dan penyelesaian dengan melibatkan pihak ketiga yaitu konsiliator. Konsiliator tidak berhak membuat keputusan dalam sengketa untuk dan atas nama para pihak sehingga keputusan akhir merupakan proses konsiliasi yang diambil sepenuhnya oleh para pihak dalam sengketa yang dituangkan dalam bentuk kesepakatan diantara mereka

Penyelesaian sengketa konsumen bisa melalui berbagai metode, antara lain arbitrase, konsiliasi, dan mediasi. Hasil penyelesaian perkara tersebut dicantumkan dalam perjanjian tertulis. Agar kuat secara hukum, perjanjian dilampirkan keputusan majelis yang dibubuhi tanda tangan ketua dan anggota majelis. Adapun bentuk putusan majelis BPSK berupa perdamaian, gugatan dikabulkan, serta gugatan ditolak. Apa pun putusan BPSK, semua itu bersifat final dan memiliki kekuatan hukum. Eksekusi putusan BPSK bisa diajukan kepada Pengadilan Negeri tempat konsumen yang merasa dirugikan. Melihat peraturan dalam Pasal 54 Ayat 3 Undang-Undang Perlindungan Konsumen, putusan BPSK tidak mungkin bisa diajukan banding. Hal senada juga diungkapkan dalam Keputusan Menteri Perindustrian dan Perdagangan Nomor 350/MPP/Kep/12/.

Namun akan melihat hal sebaliknya di Pasal 56 Ayat 2 Undang-Undang Perlindungan Konsumen. Di situ tertulis, bahwa ada peluang untuk mengajukan banding ke pengadilan negeri setempat. Pihak yang bersengketa diberikan waktu tenggang 14 hari pasca pembacaaan putusan BPSK. Sayangnya, permasalahan kerap timbul akibat BPSK tidak menegaskan adanya keberatan secara terbatas. ${ }^{14}$

Undang-Undang Informasi dan Transaksi Elektronik (UU ITE)Penyelesaian sengketa dalam transakasi e-commerce diatur dalam Undang-Undang No. 11 Tahun 2008 tentang ITE Bab VIII yang menjelaskan tentang penyelesaian sengketa diatur dalam Pasal 38 dan Pasal 39 menjelaskan bahwa gugatan perdata dilakukan sesuai dengan ketentuan perundang-undangan, para pihak dapat menyelesaikan sengketa melalui abitrase atau lembaga penyelesaian sengketa alternatif lainnya.

Alur penyelesaian sengketa konsumen dengan pelaku usaha baik publik maupun privat diatur dalam Undang-Undang Nomor 8 Tahun 1999. Dalam undang-undang ini disebutkan bahwa, penuntasan masalah konsumen memiliki kekhasan. Pasalnya, pihak yang bersengketa bisa memilih beberapa lingkungan peradilan. Lingkungan peradilan tersebut meliputi, penyelesaian di pengadilan dan luar pengadilan. Hal itu sesuai dengan Pasal 45 Ayat 2 Undang-Undang Perlindungan Konsumen (UUPK), yang menyatakan bahwa penyelesaian perkara bisa dilakukan melalui cara-cara berikut ini.

\footnotetext{
${ }^{14}$ https://smartlegal.id/smarticle/layanan/perlindungan-konsumen/2019/01/02/apa-peranan-badanpenyelesaian-sengketa-konsumen-indonesia/
} 
1. Cara damai yaitu jalan damai untuk menyelesaikan sengketa konsumen tidak melibatkan BPSK ataupun pengadilan. Antara konsumen dan pelaku usaha menuntaskannya secara kekeluargaan. Pun penyelesaiannya terlepas dari aturan Pasal 1851-1864 Kitab Undang-undang Hukum Perdata. Di dalam pasal tersebut terdapat aturan syarat-syarat, kekuatan hukum, serta perdamaian yang mengikat.

2. Cara menyelesaikan sengketa lewat pengadilan yaitu konsumen juga bisa memilih penyelesaian lewat pengadilan. Upaya ini wajib mengikuti aturan-aturan di peradilan umum, segala keputusannya berada di tangan majelis yang menangani sengketa konsumen dan pelaku usaha. Penyelesaian perkara lewat BPSK.

3. Cara ketiga adalah lewat BPSK. Berikut alur penyelesaian sengketa melalui BPSK.

Transaksi jual beli meskipun dilakukan secara online, berdasarkan UU ITE dan PP PSTE tetap diakui sebagai transaksi elektronik yang dapat bertanggung jawab. Persetujuan untuk membeli barang secara online dengan cara melakukan klik persetujuan atas transaksi merupakan bentuk tindakan penerimaan yang menyatakan persetujuan dalam kesepakatan pada transaksi elektronik. Tindakan penerimaan tersebut biasanya didahului pernyataan persetujuan atas syarat dan ketentuan jual beli secara online yang dapat kami katakan juga sebagai salah satu bentuk Kontrak Elektronik.

Dalam hal transaksi elektronik, maka gugatan ganti rugi tersebut dapat dilakukan apabila pelaku usaha tidak menjalankan kewajibannya sebagaimana diatur dalam UUPK dan PP PSTE sebagai penyelenggara transaksi elektronik. Kewajiban pelaku usaha dalam transaksi elektronik diatur dalam pasal 49 PP PSTE yaitu:

1. Pelaku usaha yang menawarkan produk melalui sistem elektronik wajib menyediakan informasi yang lengkap dan benar berkaitan dengan syarat kontrak, produsen, dan produk yang ditawarkan.

2. Pelaku usaha wajib memberikan kejelasan informasi tentang penawaran kontrak atau iklan.

3. Pelaku usaha wajib memberikan batas waktu kepada konsumen untuk mengembalikan barang yang dikirim apabila tidak sesuai dengan perjanjian atau terdapat cacat tersembunyi.

4. Pelaku usaha wajib menyampaikan informasi mengenai barang yang telah dikirim.

5. Pelaku usaha tidak dapat membebani konsumen mengenai kewajiban membayar barang yang dikirim tanpa dasar kontrak.

Artinya, konsumen berhak untuk menggugat ganti rugi kepada pelaku usaha yang tidak memenuhi kewajiban tersebut sehingga timbul kerugian dari pihak konsumen. Selain itu, pelaku usaha juga terikat dengan ketentuan yang disepakati dalam kontrak antara pelaku usaha dan konsumen. Selain itu, pelaku usaha juga betanggung jawab atas iklan yang diproduksi dan segala akibat yang ditimbulkan oleh iklan tersebut. Dengan demikian, apabila pelaku usaha tidak menepati janjinya sebagaimana disepakati dalam kontrak pada suatu transaksi atau produk yang diterima konsumen tidak sesuai dengan 
iklan dari pelaku usaha, maka konsumen dapat melapor ke BPSK untuk meminta pertanggungjawaban dari pelaku usaha.

Selanjutnya, dilihat dari sanksi administrasi berupa penetapan ganti kerugian paling banyak sebesar Rp 200.000.000,- yang dapat dibebankan kepada pelaku usaha. Hal ini menunjukkan bahwa sebenarnya BPSK tersebut dibentuk untuk menangani penyelesaian sengketa konsumen dengan proses Penyelesaian Sengketa Konsumen Ditinjau dari Hukum Acara Serta Kendala Implementasinya, Lihat Pasal 60 ayat (2) UUPK jumlah nilai yang kecil. Bagi penyelesaian sengketa untuk kasus yang sederhana dan berskala kecil, pengadilan bukanlah pilihan yang efektif. Di samping biaya perkara yang harus dikeluarkan cukup besar, proses penyelesaian sengketa memakai hukum acara yang formal dan memerlukan waktu yang lama. Penyelesaian perkara di pengadilan justru seringkali tidak memberikan keadilan atau kepuasan bagi pihak yang bersengketa. $^{15}$

Penyelesaian sengketa konsumen melalui BPSK pada dasarnya merupakan penyelesaian sengketa di luar pengadilan. BPSK diberi kewenangan untuk menyelesaikan sengketa konsumen dengan cara melalui mediasi atau arbitrase atau konsiliasi. Metode tersebut pada dasarnya merupakan metode Alternatif Penyelesaian Sengketa yang juga diatur dalam Undang-Undang Arbitrase. Dalam hal penyelesaian sengketa melalui arbitrase, Undang-undang Arbitrase mengatur bahwa sengketa yang dapat diselesaikan melalui arbitrase hanya sengketa di bidang perdagangan dan mengenai hak yang menurut hukum dan peraturan perundang-undangan dikuasai sepenuhnya oleh pihak yang bersengketa. Selanjutnya, mengenai ruang lingkup perdagangan dapat ditemukan pada penjelasan pasal 66 huruf b Undang-Undang Arbitrase, yaitu kegiatan-kegiatan antara lain di bidang :

a. Perniagaan;

b. Perbankan;

c. Keuangan;

d. Penanaman modal;

e. Industri;

f. Hak kekayaan intelekual.

Sedangkan, pasal 5 ayat (2) Undang-Undang Arbitrase mengatur bahwa sengketa yang tidak dapat diselesaikan melalui arbitrase adalah sengketa yang menurut peraturan perundang-undangan tidak dapat diadakan perdamaian. Dengan demikian dapat disimpulkan bahwa menurut Undang-undang Arbitrase, sengketa yang dapat diselesaikan melalui arbitrase adalah sengketa di bidang perdagangan dan mengenai hak yang menurut hukum dan peraturan perundang-undangan dikuasai sepenuhnya oleh pihak yang bersengketa serta berdasarkan peraturan perundang-undangan dapat dilakukan perdamaian

\footnotetext{
${ }^{15}$ Susanti Adi Nugoho, op.cit., hal. 85
} 
Dengan demikian, pada transaksi elektronik yang dilakukan, dapat menggunakan instrumen UU ITE dan/atau PP PSTE sebagai dasar hukum dalam menyelesaikan permasalahan. Terkait dengan perlindungan konsumen, Pasal 49 ayat (1) PP PSTE menegaskan bahwa Pelaku Usaha yang menawarkan produk melalui Sistem Elektronik wajib menyediakan informasi yang lengkap dan benar berkaitan dengan syarat kontrak, produsen, dan produk yang ditawarkan.

Jika barang yang terima tidak sesuai dengan yang diperjanjikan, Pasal 49 ayat (3) PP PSTE mengatur khusus tentang hal tersebut, yakni Pelaku Usaha wajib memberikan batas waktu kepada konsumen untuk mengembalikan barang yang dikirim apabila tidak sesuai dengan perjanjian atau terdapat cacat tersembunyi. Selain kedua ketentuan tersebut di atas, apabila ternyata barang yang terima tidak sesuai dengan foto pada, dapat menggugat Pelaku Usaha (dalam hal ini adalah penjual) secara perdata dengan dalih terjadinya wanpretasi atas transaksi jual beli yang lakukan dengan penjual.

\section{Simpulan}

Penyelesaian sengketa Konsumen Menurut Undang-undang Perlindungan Konsumen No 8 tahun 1999 membagi penyelesaian sengketa konsumen menjadi 2 bagian, yaitu: 1) Penyelesaian sengketa di luar pengadilan dan 2) Penyelesaian sengketa secara damai oleh para pihak sendiri dan penyelesaian sengketa melalui lembaga yang berwenang, yaitu melalui BPSK dengan menggunakan mekanisme melalui konsiliasi, mediasi atau arbitrase. Sementara Penyelesaian sengketa dalam transakasi e-commerce diatur dalam Undang-Undang No. 11 Tahun 2008 tentang ITE Bab VIII yang diatur dalam Pasal 38 dan Pasal 39. Menurut Undang-Undang Perdagangan, Penyelesaian sengketa berdasarkan Undang-Undang Nomor 7 Tahun 2014 tentang Perdagangan Pasal 65 ayat (5) dan ayat (6) yang mengatur sengketa terkait dengan transaksi dagang melalui sistem elektronik.

\section{Daftar Pustaka}

\section{Buku}

Abdulkadir Muhammad, 2004, Hukum dan Penelitian Hukum Cetakan I, Bandung, PT Citra Aditya Bakti

Bambang Sunggono, 2011, Metodologi Penelitian Hukum, Jakarta, PT Raja Grafindo

Ronny Hanitijo Soemitro, 2008, Metode Penelitian Hukum dan Jurimetri, Jakarta, Galia Indonesia

Yusus Shofie, 2003, Penyelesaian Sengketa Konsumen Menurut UUPK, Bandung, Citra Aditya Bakti 


\section{Jurnal}

Kurniawan, "Permasalahan dan Kendala Penyelesaian Sengketa Konsumen melalui Badan Penyelesaian Sengketa Konsumen", (Januari 2012)

Mukti Fajar, Penyelesaian Sengketa Konsumen, Materi Perkuliahan Fakultas Hukum Universitas Muhammadiyah Yogyakarta

Ph. Visser't Hoft, 2009, Penemuan Hukum, Bandung, Fakultas Hukum Universitas Parahiyangan

R. Subekti, R. Tjitrosudibio, 2003, Kitab Undang-Undang Hukum Perdata, Jakarta, Pradnya Paramita

Sunaryati Hartono, 1994, Penelitian Hukum Di Indonesia Pada Akhir Abad ke-20, Bandung, Alumni

\section{Internet}

Anonim, Arti Dan Penjelasan COD Dalam Jual Beli Online, 2018, https://infopeluangusaha.org/arti-dan-penjelasan-cod-dalam-jual-beli,

diakses pada tanggal 10 November 2018 pukul 14.30 WIB

Anonim, Langkah Tahap Cara Transaksi Jual Beli Online Barang Dan Jasa Di Internet Online, 2010, http://www.organisasi.org/1970/01/langkah-tahap-cara-transaksijual-beli-barang-dan-jasa-di-internet-online.html?m=1\#.XUxA-GQxdkw, diakses pada tanggal 01 Agustus 2019 pukul 14.00 WIB

\section{Undang-Undang}

Undang-Undang Nomor 8 Tahun 1999 Tentang Perlindungan Konsumen

Kitab Undang-Undang Hukum Perdata

Undang-Undang Nomor 11 Tahun 2008 Tentang Informasi dan Transaksi Elektronik

Undang-Undang Nomor 7 Tahun 2014 Tentang Perdagangan 